\title{
A Síndrome do alienista e os projetos de seletividade penal: uma análise das políticas criminais de tolerância zero à luz de Machado de Assis
}

\author{
The alienist syndrome and the criminal selectivity projects na \\ anlysis of the zero tolerance criminal policies in the of Machado \\ de Assis
}

Edson Vieira da Silva Filho ${ }^{1}$

Allan Rovani ${ }^{2}$

\begin{abstract}
RESUMO:
O trabalho tem seu objeto de estudo especificamente direcionado ao direito penal e às ciências multidisciplinares - criminologia, sociologia, antropologia, instrumentalização de políticas criminais, etc. - e problemática geral que propõe uma comparação entre as contribuições da sociologia na criminologia e a obra literária de Machado de Assis, "O Alienista". Passando pela bibliografia ao final enumerada, o tema tem seu desenvolvimento em dois tópicos fundamentais: o desenvolvimento de uma nova teoria da punição pela retórica do "milagre", que a política criminal de tolerância zero nostalgicamente poderia proporcionar, em paralelo à ciência de intolerância de Dr. Bacamartes; o início da crítica à etiologia criminológica determinista, enquanto projeto de seleção e resposta ao mal socialmente considerado, pelo advento do paradigma da teoria do etiquetamento e seu paralelo com a situação de Itaguaí, terra dos experimentos do alienista. Não obstante a utilização de diversos autores da criminologia, e até mesmo os específicos críticos das políticas de tolerância zero, os trabalhos de Alessandro Baratta, Eugenio Raúl Zaffaroni e Nilo Batista representam os referenciais teóricos no que diz respeito à criminologia crítica e à crítica do direito penal. Assim, o objetivo geral da pesquisa, bem como sua própria conclusão, pretende provocar a reflexão crítica em relação à instrumentalização de práticas penais que possuem sustentação em teorias da boa gestão e defesa da ordem social, ainda que ignore seu caráter seletivo, discriminatório e violento e desencadeie as consequências que, assim como na realidade social, podem ser observadas na ficção de Machado de Assis.
\end{abstract}

\section{PALAVRAS-CHAVE:}

\footnotetext{
${ }^{1}$ Pós Doutor pela UNISINOS, sob a orientação do Professor Doutor Lenio Luiz Streck; Doutor em Direito pela UNESA; Mestre em Direito pela Universidade Federal do Paraná; Mestre em Direito pela Universidade São Francisco (2002); Graduado em Direito pela PUC, Belo Horizonte/MG (1986). Delegado de Polícia Classe Geral, aposentado - Polícia Civil do Estado de Minas Gerais. Gestor do Núcleo de Atividades Complementares da Faculdade de Direito do Sul de Minas. Professor Adjunto e membro do Núcleo Docente Estruturante da Faculdade de Direito do Sul de Minas. Professor do PPGD da FDSM. Vice-Presidente da Fundação Sul Mineira de Ensino. 2 Advogado Bacharel em Direito pela Faculdade de Direito do Sul de Minas. Pós-graduando em Direito Constitucional pela Faculdade de Direito do Sul de Minas e em Direito Penal e Criminologia pela Pontifícia Universidade Católica do Rio Grande do Sul. Estudante de Hermenêutica Jurídica, Criminologia e Sociologia aplicadas ao Direito Penal pelo Grupo de Pesquisa "Razão Crítica e Justiça Penal", certificado pela Faculdade de Direito do Sul de Minas e inserido no Diretório de Grupos de Pesquisa do CNPq.
} 
Tolerância Zero; Teoria da Rotulação; O Alienista.

\begin{abstract}
:
The work has its a specific study aimed at criminal law and multidisciplinary sciences criminology, sociology, anthropology, instrumentalization of criminal policies, etc. - and general problematic that proposes a comparison between the contributions of sociology in criminology and Machado de Assis' literary work, "The Alienist". Passing through the bibliography to the final listed, the theme has its development in two fundamental topics: the rupture with identity to the accountability of the different, the development of a new punishment theory by the "miracle" rhetoric that the zero-tolerance criminal policy nostalgically could provide, in parallel with Dr. Bacamartes' science of intolerance; the beginning of the criticism to deterministic criminological etiology as a project of selection and response to the evil socially considered, by the advent of the labeling theory paradigm and its parallel with the situation of Itaguaí, land of the experiments of the alienist. Despite the use of several authors of criminology, and even the specific critics of zero-tolerance policies, Alessandro Baratta, Eugenio Raúl Zaffaroni and Nilo Batista works represent the theoretical reference with respect to critical criminology and the criticism to penal law. Thus, the general objective of the research, as well as its own conclusion, aims to provoke the critical reflection regarding the instrumentalisation of penal practices that have support in theories of good management and defense of the social order, even though it ignores its selective, discriminatory and violent character and unleash the consequences which, as in the social reality, can be observed in Machado de Assis' fiction.
\end{abstract}

\title{
KEYWORDS:
}

Zero-tolerance; Labeling Theory; The Alienist.

\section{INTRODUÇÃO}

A síndrome do alienista é um termo, utilizado na reflexão, para por a obsessão de um médico, filho de nobres brasileiros, apaixonado pela ciência do espírito da loucura, em paralelo à obsessão pela defesa social extraída dos discursos que procuraram, de todas as formas, legitimar políticas criminais pautadas pela prática da intolerância aos diferentes e socialmente inadequados. Com aporte teórico nas contribuições da ecologia criminal, ${ }^{3}$ que retirou a etiologia criminológica do homem bioantropologicamente considerado para difundir a etiologia do

\footnotetext{
${ }^{3}$ BATISTA, Vera Malaguti. Introdução crítica à criminologia brasileira. 2.ed. Rio de Janeiro: Revan, 2011. p.68.
} 
homem sociologicamente considerado, ${ }^{4}$ a política criminal da tolerância zero, se valendo, ainda que de modo velado, da teoria sociológica das janelas quebradas, produziu uma forma muito própria de seletividade penal ${ }^{5}$ a partir de meados de 1950.

O obsessivo médico da obra de Machado de Assis é Dr. Bacamartes, que, como dito, se aventurou pelas ciências do espírito da loucura de forma apaixonada, a ponto de dedicar sua vida exclusivamente à medicina. Partiu, para tanto, de sua própria reta razão científica para buscar a correção psíquica dos internos da Casa Verde, acreditando estar à procura da cura para os males que assombram o espírito dos homens e os deixam à margem da ideal sociabilidade, no mesmo sentido que a correção moral do discurso da defesa social pregou a existência de uma correspondência negativa entre o fenômeno criminal e os valores sociais que prejudica a ideal gestão da ordem.

Portanto, a problemática passa por pesquisas bibliográficas propondo colocar a concreta situação de punição seletiva, fundada na ecologia criminal e praticada pela tolerância zero, em paralelo à ficção de Machado de Assis, procurando responder quais são as correspondências entre a realidade estadunidense e a ficção de Itaguaí, no que diz respeito às causas, enquanto razão de ser e existir, e às consequências, enquanto frutos colhidos pela prática dessa punição/tratamento despoticamente seletiva.

\section{O ALIENiSTA EM PARALELO LITERÁRIO AO DESENVOLVIMENTO DA TEORIA DA PUNIÇÃO CONTRA OS SOCIALMENTE INADEQUADOS.}

Na obra de Machado de Assis, "O Alienista", Dr. Simão Bacamarte, filho da nobreza da terra de Itaguaí e o maior dos médicos do Brasil, de Portugal e das Espanhas, com a mais nobre das intenções, como dizia, e de modo eloquente, conseguiu autorização legislativa para construir em seu pequeno vilarejo uma casa que pode ser chamada de manicômio, onde poderia

\footnotetext{
${ }^{4}$ Ibidem. p. 66.

${ }^{5}$ ZAFFARONI, Eugenio Raúl. A questão criminal. trad. Sérgio Lamarão. 1. ed. Rio de Janeiro: Revan, 2013. p.
} 158. 
ele entender e tratar os "doidos pobres", 6 que, embora incomodassem, a eles era prestado pouco caso pela comunidade. A Casa Verde contava com numerosos cubículos para os hóspedes, e, segundo o médico:

O principal nesta minha obra da Casa Verde é estudar profundamente a loucura, os seus diversos graus, classificar-lhe os casos, descobrir enfim a causa do fenômeno e o remédio universal. Este é o mistério do meu coração. Creio que com isto presto um bom serviço à humanidade. ${ }^{7}$

Assim como as "teses do milagre", 8 como foram insistentemente nomeadas pelas doutrinas de tolerância zero, Dr. Bacamarte era obstinado à procura do remédio universal para a loucura e, para tanto, convinha que fosse criado um local onde pudessem ser agrupados e estudados os loucos de toda espécie. Segundo a opinião pública, a ideia de serem agrupados os loucos de toda espécie passou rapidamente da irrelevância à garantia de aplicação da ciência e desta para à insanidade, quando da internação de um certo Costa, estimado cidadão de Itaguaí e herdeiro de grande patrimônio - embora totalmente perdido pelo herdeiro. Segundo o alienista, a ciência era ciência e não poderia deixar na rua um mentecapto, segundo suas convicções ratificadas pela Câmara. Logo tratou de retirar das ruas muitos outros estimados cidadãos de Itaguaí.

\subsection{A síndrome do alienista e os projetos de criminalização da tolerância zero: a licença literária que exprime uma realidade de punição déspota e seletiva.}

Em uma aproximação criminológica das premissas propostas pelas políticas de tolerância zero, no paralelo literário de Machado de Assis, Dr. Bacamarte se materializa na figura do intolerante ao degenerado, enquanto aquele que foge ao gênero, ao desequilibrado, enquanto aquele que foge ao equilíbrio, o anormal, enquanto aquele que foge à norma. É desse sentido que se retira a possibilidade crítica da conexão entre as referidas premissas e a obra.

Logo no início, já após os primeiros acontecimentos relativos à construção da Casa Verde e ao começo da internação dos loucos de toda espécie, ao cabo de quatro meses, a casa

\footnotetext{
${ }^{6}$ ASSIS, Machado de. Obra Completa. Rio de Janeiro: Nova Aguilar, 1994. p. 03.

${ }^{7}$ Ibidem. p. 04.

${ }^{8}$ YOUNG, Jock. A sociedade excludente: exclusão social, criminalidade e diferença na modernidade recente. Trad. Renato Aguiar. 3. rei. Rio de Janeiro: Revan, 2015. p. 181.
} 
era uma povoação, não bastando os primeiros cubículos, sendo anexada uma galeria de mais trinta e sete destes, conta Machado de Assis. A verdade é o que Vossa Reverendíssima está vendo, isso é todos os dias, ${ }^{9}$ disse o alienista ao Padre Lopes, que logo tratou de buscar uma explicação religiosa para a situação de superencarceramento, explicando entender se tratar de uma confusão ocasionada pela queda da torre de Babel, desaparecimento da língua comum e surgimento das tantas outras. É fácil confundi-las se não utilizada uma reta razão como caminho. $\mathrm{O}$ alienista não discorda da premissa que encara como uma explicação divina, mas complementa que há de existir uma explicação humana e puramente científica para o fenômeno.

Nesse momento, é importante o que aponta Salo de Carvalho: segundo o autor, os "sistemas herméticos de pensamento cultuadores de verdades e valores universais" 10 encontram grandes dificuldades quando suas bases epistemológicas são desconstruídas pela imersão do mundo científico na complexidade das sociedades contemporâneas. Complementa que a “assunção da complexidade e a aceitação de dificuldades desdobram reais possibilidades de erro, e, consequentemente, incertezas". ${ }^{11}$ Dr. Bacamarte não possuía incertezas para as quais acreditava não existir solução científica, mas seus erros podem ser constatados, com a certeza dada por Machado de Assis, ao final da obra. A razão cientificista do alienista, bem aos moldes ontológicos positivistas, ${ }^{12}$ o levou a crer na reta razão, ${ }^{13}$ por que é ela o parâmetro para a normalidade de verdades e valores universais, cultuada pelos sistemas herméticos do pensamento, conforme o que afirma Salo de Carvalho. A razão, disse o alienista, é o perfeito equilíbrio de todas as faculdades; fora daí, insânia, insânia e só insânia.

Não obstante, o médico de Itaguaí era assíduo no seu trabalho, analisava a profissão de cada louco, costumes, acidentes de infância e da mocidade, antecedentes de família, muito próximo à etiologia que a Escola de Chicago produziu. ${ }^{14}$ A política criminal de tolerância zero surgiu como uma vertente da ecologia criminal $^{15}$ e do paradigma do positivismo

\footnotetext{
${ }^{9}$ ASSIS, Machado de. Obra Completa. Rio de Janeiro: Nova Aguilar, 1994. p. 04.

${ }^{10}$ CARVALHO, Salo de. Antimanual de criminologia. 6. ed. rev. e ampl. São Paulo: Saraiva, 2015. p. 84.

${ }^{11}$ Ibidem. p. 84.

12 BARATTA, A. Criminologia crítica e crítica do Direito Penal: introdução à sociologia do Direito Penal. Trad. Juarez Cirino dos Santos. 3. ed. Rio de Janeiro: Revan, 2002. p. 40

${ }^{13}$ SILVA FILHO, Edson Vieira da. Há que se revisitar Kant em uma leitura do Direito Penal Contemporâneo?. In: FIGUEIREDO, E. H. L.; CAMPOS MONACO, G. F. de; MAGALHÃES, J. L. Q de. (Coord.). Constitucionalismo e Democracia. 1. ed. Rio de janeiro: Elsevier, 2012. p. 225.

${ }^{14}$ BATISTA, Vera Malaguti. Introdução crítica à criminologia brasileira. 2.ed. Rio de Janeiro: Revan, 2011. p.66.

${ }^{15}$ SHECAIRA, Sérgio Salomão. Criminologia. 6. ed. São Paulo: Revista dos Tribunais, 2014. p. 160.
} 
bioantropológico não se afastou, ${ }^{16}$ dessa mesma forma, o alienista também analisava hábitos, as aversões, as simpatias, as palavras, os gestos e as tendências de seus loucos e para tudo isso estudava os meios paliativos e curativos das enfermidades psíquicas. A Casa Verde era um mundo, dizia o alienista, onde há o governo temporal e o governo espiritual, e sua gerência, ainda que descentralizada administrativamente, estava em seu comando, como o déspota responsável pela vasta classificação ${ }^{17}$ dos enfermos - quem, por que e como ser diagnosticado e tratado.

Em certa altura da obra, Dr. Bacamarte desenvolve uma nova teoria segundo os estudos até ali produzidos, onde tratou de ampliar a abrangência de suas teses sobre a loucura, por que, para ele, até aquele momento, a insânia era somente uma ilha perdida no oceano da razão, mas suspeitava se tratar de um continente, inclusive apontando personagens célebres da história, como Maomé, Calígula, etc. Ainda que não acatado pelo alienista, que preferiu começar pela execução antes da divulgação, pelo seu boticário, Crispim Soares, lhe foi sugerido que, para "ampliar o território da loucura", ${ }^{18}$ fosse utilizado um eficaz meio de comunicação, a matraca, equivalente à imprensa que Itaguaí não dispunha.

A matraca consistia no pagamento de uma pessoa incumbida na tarefa de andar pela cidade, com uma matraca na mão, reunir pessoas e propagar o que foi contratado para propagar. Pela regular e correta utilização de tal meio de comunicação, um dos vereadores da cidade era visto como um exímio educador de cobras e macacos, mesmo sem jamais ter domesticado um só desses. As "teses do milagre" 19 produziram grandes seminários, conferências e declarações escritas em todo o globo, ${ }^{20}$ onde, conforme demonstra Young, foram reproduzidas as retóricas das janelas quebradas ${ }^{21}$ e do marco conquistado por Nova Iorque com a adoção de uma política criminal de intolerância máxima a todo e qualquer desvio.

\footnotetext{
${ }^{16}$ ANITUA, Gabriel Ignacio. Histórias dos pensamentos criminológicos. trad. Sérgio Lamarão. 1. reimp. Rio de Janeiro: Revan, 2015. p. 559.

${ }^{17}$ Anitua demonstra que, na psiquiatria tradicional, existia essa prática de "classificação" dos enfermos, que se limitava a assinalar dentro de qual patologia o paciente podia ser enquadrado, ao invés de pensar nas necessidades do indivíduo e de se o melhor era "trata-lo" clinicamente. ANITUA, Gabriel Ignacio. Histórias dos pensamentos criminológicos. trad. Sérgio Lamarão. 1. reimp. Rio de Janeiro: Revan, 2015. p. 580.

${ }^{18}$ ASSIS, Machado de. Obra Completa. Rio de Janeiro: Nova Aguilar, 1994. p. 09.

${ }^{19}$ YOUNG, Jock. A sociedade excludente: exclusão social, criminalidade e diferença na modernidade recente. Trad. Renato Aguiar. 3. rei. Rio de Janeiro: Revan, 2015. p. 181.

${ }^{20}$ WACQUANT, Loïc. As prisões da miséria. 2. ed. Rio de Janeiro: Zahar, 2011. p. 38.

${ }^{21}$ YOUNG, Jock. A sociedade excludente: exclusão social, criminalidade e diferença na modernidade recente. Trad. Renato Aguiar. 3. rei. Rio de Janeiro: Revan, 2015. p. 181.
} 
Wacquant fala especialmente da globalização da tolerância zero: segundo o autor, ${ }^{22}$ dentre vários outros exemplos, cita que Henry McLeish, ministro do Interior escocês, publicou uma declaração intitulada “A tolerância zero vai limpar nossas ruas"; em 1998, o presidente do México lança uma "Cruzada nacional contra o crime”; no Brasil, em janeiro de 1999, depois da visita de dois altos funcionários da polícia de Nova York, Joaquim Roriz, governador de Brasília à época, anuncia a aplicação da "tolerância zero" com a contratação de oitocentos policiais civis e militares suplementares em resposta a uma onda de crimes de sangue. Em complemento, Young demonstra que, entre os fatores que contribuem com facilidade de propagação dos milagres pelo globo, estão os meios de comunicação em massa que propagam o atípico, aquilo que surpreende e que está em contraste com a "normalidade" cotidiana e por isso causa interesse e sensação de qualidade. ${ }^{23}$

Com o papel de matraca muito bem alinhado, William Bratton, comissário da polícia de Nova Iorque, que se intitulava o responsável pelo milagre nova-iorquino e que anteriormente havia dito em uma conferência na Heritage Foundation que, em sua cidade, sabia onde estava o inimigo, ${ }^{24}$ comunicava que "o crime [tinha sido] derrotado em Nova Iorque: podem pôr a culpa na polícia". ${ }^{25}$

Da mesma forma ocorrida nos Estados Unidos, na ficção, o alienista preferiu colocar sua nova teoria em prática e partir dos resultados para posteriormente talvez lhe atribuir o sucesso: "sempre haverá tempo de a dar à matraca, concluiu ele". Importante reafirmar que, como apontam todos os críticos da política nova-iorquina trabalhados até aqui, o real fator por trás do sucesso da redução na criminalidade não foi a aplicação da punição contra tudo e contra todos, mas a prosperidade econômica ${ }^{26}$ experimentada, à época, pelas classes mais desfavorecidas norte-americanas. ${ }^{27}$ Garland ainda acrescenta a necessidade de se creditar o sucesso à resiliência dos controles sociais nas comunidades de trabalhadores, ao impacto da

\footnotetext{
${ }^{22}$ WACQUANT, Loïc. As prisões da miséria. 2. ed. Rio de Janeiro: Zahar, 2011. p. 38.

${ }^{23}$ YOUNG, Jock. A sociedade excludente: exclusão social, criminalidade e diferença na modernidade recente. Trad. Renato Aguiar. 3. rei. Rio de Janeiro: Revan, 2015. p. 189.

${ }^{24}$ WACQUANT, Loïc. As prisões da miséria. 2. ed. Rio de Janeiro: Zahar, 2011. p. 34.

25 YOUNG, Jock. A sociedade excludente: exclusão social, criminalidade e diferença na modernidade recente. Trad. Renato Aguiar. 3. rei. Rio de Janeiro: Revan, 2015. p. 181.

${ }^{26}$ ANITUA, Gabriel Ignacio. Histórias dos pensamentos criminológicos. trad. Sérgio Lamarão. 1. reimp. Rio de Janeiro: Revan, 2015. p. 483.

${ }^{27}$ SHECAIRA, Sérgio Salomão. Criminologia. 6. ed. São Paulo: Revista dos Tribunais, 2014. p. 160.
} 
disciplina laboral, à doutrina religiosa, às campanhas morais das igrejas e das organizações de reforma e às formas de controle mais íntimas como a família, os bairros e os locais de trabalho. ${ }^{28}$

Machado de Assis faz o prenúncio do terror que se seguiu em Itaguaí depois de posta em prática a nova teoria do alienista. Um estimado cidadão fora internado na Casa Verde e, após ele, mais tantos outros. A cidade se revolta e assim só aconteceu em razão da estima por determinadas pessoas atingidas pela ciência do alienista, lembrando que, a essa altura da existência da Casa Verde suas acomodações não eram suficientes para a tamanha demanda de loucos.

O prenúncio do terror é esperado, já que uma ciência, assim considerada pelas próprias palavras do alienista, ${ }^{29}$ paralela à tolerância zero, por que entre ambas há uma comunicação de fundamentos, facilmente perde o controle por que, de modo déspota e em nome de uma governabilidade, como acrescenta Alessandro de Giorgi, ${ }^{30}$ pune tudo, por menor que seja, e pune todos, desde que o termo "todos" se resuma às camadas de vulnerabilidade social. ${ }^{31}$ Mas, a síntese da seletividade diz que, se o controle perdido se mantém na canalha, ${ }^{32}$ não há problema - fiquem em seu lugar, ou cortamos a cabeça de quem incomodar, ${ }^{33}$ como diz Zaffaroni.

O despotismo de Bacamarte encarcerou a prima de Costa, o estimado cidadão, quando a pobre senhora resolveu argumentar para interceder pela sanidade de seu primo. Seu argumento beirou a superstição quando explicou ao alienista que uma antiga praga de família poderia ser a causa dos infortúnios de Costa, o que rapidamente chamou a atenção do alienista, que fixou agudos olhos contra a senhora e carinhosamente a dirigiu à galeria dos alucinados.

Atingidos os cidadãos estimados da vila de Itaguaí, não demorou muito para que uma generalizada revolta revirasse o pequeno lugar, sobretudo quando levado à população o terror da notícia de que o alienista havia levado à internação uma senhora perfeitamente ajuizada, que

\footnotetext{
${ }^{28}$ GARLAND, David. A cultura do Controle: crime e ordem social na sociedade contemporânea. Rio de Janeiro: Revan, 2014. p. 102.

${ }^{29}$ ASSIS, Machado de. Obra Completa. Rio de Janeiro: Nova Aguilar, 1994. p. 01.

${ }^{30}$ DE GIORGI, Alessandro. A miséria governada através do sistema penal. 2. reimp. Rio de Janeiro: Revan, 2013. p. 85.

${ }^{31}$ ZAFFARONI, Eugenio Raul; BATISTA, Nilo. Direito Penal Brasileiro: Teoria Geral do Direito Penal. Vol. I.

4. ed. Rio de Janeiro: Revan, 2011. p. 46.

${ }^{32}$ SHECAIRA, Sérgio Salomão. Criminologia. 6. ed. São Paulo: Revista dos Tribunais, 2014. p. 161.

${ }^{33}$ ZAFFARONI, Eugenio Raúl. A questão criminal. trad. Sérgio Lamarão. 1. ed. Rio de Janeiro: Revan, 2013. p. 158.
} 
não tinha outro crime senão o de interceder por um infeliz e, logo após, mais tantos outros. A política de tolerância zero aplicada nos Estados Unidos não fez diferente e aumentou exponencialmente a população carcerária, ${ }^{34}$ ainda que o número de delitos registrados tenha caído também exponencialmente no mesmo período. ${ }^{35}$

Nesse contexto, mais precisamente por volta da década de 60, surgem as teorias do etiquetamento partindo da publicação da obra sociológica ${ }^{36}$ "Outsiders" de Howard Becker e avançando por meio da psicologia criminal produzida por Edwin Lemert, demonstrando as consequências dos estigmas sociais ampliados pelo despotismo de uma política de intolerância aos diferentes, dentre elas, as principais: a recepção e incorporação do estigma ${ }^{37}$ à personalidade do próprio estigmatizado e a recepção, incorporação e reprodução ideológica, no sentido de Althusser, ${ }^{38}$ dos valores internos do grupo seleto de estigmatizados, em um sistema que não consegue reproduzir nada além dele mesmo.

\section{O DESENVOLVIMENTO DA TEORIA DO ETIQUETAMENTO COMO CRÍTICA À ETIOLOGIA DETERMINISTA CRIMINOLÓGICA: O ALIENISTA E OS PROJETOS DE ROTULAÇÃO, SELETIVIDADE E RESPOSTA AO MAL DOS SOCIALMENTE INADEQUADOS.}

Sob influência da fenomenologia existencialista heideggeriana, ${ }^{39}$ em que a abordagem do conhecimento sobre a realidade social parte do sentido dado às coisas por sua construção concreta, conforme explica Anitua, ${ }^{40}$ a sociologia criminológica dá vida à inédita premissa de que não há uma realidade ontológica do delito, "o mesmo delito não seria definido por suas

\footnotetext{
${ }^{34}$ WACQUANT, Loïc. As prisões da miséria. 2. ed. Rio de Janeiro: Zahar, 2011. p. 28.

35 Ibidem. p. 28.

${ }^{36}$ BARATTA, A. Criminologia crítica e crítica do Direito Penal: introdução à sociologia do Direito Penal. Trad. Juarez Cirino dos Santos. 3. ed. Rio de Janeiro: Revan, 2002. p. 87.

${ }^{37}$ Ibidem. p. 89.

38 ALTHUSSER, Louis. Aparelhos Ideológicos de Estado. 10. ed. Rio de Janeiro: Graal, 2007. p. 52.

${ }^{39}$ BILLIER, Jean-Cassien; MARYIOLI, Aglaé. História da Filosofia do Direito. Trad. Maurício de Andrade. 1. ed. Barueri, SP: Manole, 2005. p. 362.

${ }^{40}$ ANITUA, Gabriel Ignacio. Histórias dos pensamentos criminológicos. trad. Sérgio Lamarão. 1. reimp. Rio de Janeiro: Revan, 2015. p. 574.
} 
causas e consequências, como dizia o paradigma etiológico, mas sim por sua convencionalidade interpretativa". ${ }^{41}$

Nesse mesmo sentido, segundo Baratta, a etiologia criminológica é a determinação das causas que dão existência ao fenômeno criminal considerado em si mesmo como um ponto de partida, "uma entidade natural para explicar", ${ }^{42}$ sendo característica da metodologia positivista, da qual os sociólogos estadunidenses não se afastaram. ${ }^{43}$ Ainda que considerado pelas doutrinas críticas do direito penal como uma teoria limitada em sua abordagem,${ }^{44}$ interessa perceber que a teoria do etiquetamento é considerada uma revolução científica, ${ }^{45}$ por que, ao iniciar o rompimento com a etiologia determinista, ${ }^{46}$ deu abertura ao enfrentamento das teorias legitimadoras da pena por trás dos processos de criminalização e suas consequências, sendo o limite da criminologia liberal, segundo Vera Malaguti. ${ }^{47}$ Tal abertura permitiu um desenvolvimento crítico contra a ideia de correspondência negativa entre o fenômeno criminal e os valores sociais - muito própria da ideologia penal da defesa social.

É perceber, segundo o combate ao determinismo promovido pela teoria do etiquetamento, que o crime não existe enquanto representação do mal em uma entidade natural, como explica Baratta. ${ }^{48} \mathrm{~A}$ interpretação de condutas que comprometem um determinado projeto civilizatório acontece a partir das existências concretas e das construções sociais que utilizam de suas políticas criminais como um artifício para contenção de violações a tal projeto.

A política criminal de tolerância zero, partindo da produção sociológica da ecologia criminal, de sua metodologia e de suas conclusões em relação à sociedade desorganizada ou organizada de forma diferente em subculturas, ${ }^{49}$ traz um forte apelo à ideologia penal da defesa social, já que, em relação à anomia, por exemplo, para o Estado e para as fundações privadas

\footnotetext{
${ }^{41}$ Ibidem. p. 586.

42 BARATTA, A. Criminologia crítica e crítica do Direito Penal: introdução à sociologia do Direito Penal. Trad. Juarez Cirino dos Santos. 3. ed. Rio de Janeiro: Revan, 2002. p. 86.

43 ZAFFARONI, Eugenio Raúl. A questão criminal. trad. Sérgio Lamarão. 1. ed. Rio de Janeiro: Revan, 2013. p. 116.

${ }^{44}$ SHECAIRA, Sérgio Salomão. Criminologia. 6. ed. São Paulo: Revista dos Tribunais, 2014. p. 288.

45 BARATTA, A. Criminologia crítica e crítica do Direito Penal: introdução à sociologia do Direito Penal. Trad. Juarez Cirino dos Santos. 3. ed. Rio de Janeiro: Revan, 2002. p. 85.

${ }^{46}$ CARVALHO, Salo de. Antimanual de criminologia. 6. ed. rev. e ampl. São Paulo: Saraiva, 2015. p. 91.

${ }^{47}$ BATISTA, Vera Malaguti. Introdução crítica à criminologia brasileira. 2.ed. Rio de Janeiro: Revan, 2011 . p. 74.

${ }^{48}$ BARATTA, A. Criminologia crítica e crítica do Direito Penal: introdução à sociologia do Direito Penal. Trad. Juarez Cirino dos Santos. 3. ed. Rio de Janeiro: Revan, 2002. p. 86.

${ }^{49}$ SHECAIRA, Sérgio Salomão. Criminologia. 6. ed. São Paulo: Revista dos Tribunais, 2014. p. 159.
} 
“"não importa o problema, importa a solução", ${ }^{50}$ É principalmente nesse sentindo que a teoria do etiquetamento trabalhou, procurando desvencilhar a criminologia de tal ideologia.

\subsection{A teoria do etiquetamento levada à criminologia na forma de enfretamento ao paradigma da defesa social: a rotulação como orientação seletiva dos processos de criminalização.}

O Labeling Approach, como qualquer movimento ideológico, ${ }^{51}$ teve, como pano de fundo, um contexto social $^{52}$ que contribuiu para elaboração e fundamentação de suas constatações: a crescente insatisfação com o "opulento"”53 sistema econômico norte americano, com a pressão de sucesso econômico, a marginalização de setores que não podiam ter "acesso à educação por conta da cor da pele, ou ao trabalho por conta da condição feminina" ${ }^{54}$ dentre vários e vários outros fatores, ${ }^{55}$ causaram um grave desequilíbrio axiológico social. Passando por movimentos sociais que, como demonstra Shecaira, foram os fermentos da ruptura metodológica com a velha criminologia, quando, de uma hora para outra, as aplicações da lei penal em tolerância zero "transformaram pessoas comuns em criminosos", 56 o discurso da defesa social se desgastou. Em razão desses vários fatores, David Garland explica $^{57}$ não ser possível resumir o abandono do correcionalismo ${ }^{58}$ às críticas puramente criminológicas, até mesmo por que nem o Labeling Approach foi capaz de abandonar completamente. ${ }^{59}$

\footnotetext{
${ }^{50}$ ANITUA, Gabriel Ignacio. Histórias dos pensamentos criminológicos. trad. Sérgio Lamarão. 1. reimp. Rio de Janeiro: Revan, 2015. p. 561.

${ }^{51}$ ALTHUSSER, Louis. Aparelhos Ideológicos de Estado. 10. ed. Rio de Janeiro: Graal, 2007. p. 52.

${ }^{52}$ REALE, Miguel. Fontes e modelos do direito: para um novo paradigma hermenêutico. São Paulo: Saraiva, 1994. p. 21.

${ }_{53}$ ANITUA, Gabriel Ignacio. Histórias dos pensamentos criminológicos. trad. Sérgio Lamarão. 1. reimp. Rio de Janeiro: Revan, 2015. p. 569.

${ }^{54}$ Ibidem. p. 569.

${ }^{55}$ GARLAND, David. A cultura do Controle: crime e ordem social na sociedade contemporânea. Rio de Janeiro: Revan, 2014. p. 181.

${ }^{56}$ SHECAIRA, Sérgio Salomão. Criminologia. 6. ed. São Paulo: Revista dos Tribunais, 2014. p. 255.

${ }^{57}$ GARLAND, David. A cultura do Controle: crime e ordem social na sociedade contemporânea. Rio de Janeiro: Revan, 2014. p. 181.

${ }^{58}$ Ibidem. p. 143.

${ }^{59}$ BARATTA, A. Criminologia crítica e crítica do Direito Penal: introdução à sociologia do Direito Penal. Trad. Juarez Cirino dos Santos. 3. ed. Rio de Janeiro: Revan, 2002. p. 93.
} 
É a chamada teoria da reação social em seu nascimento, ${ }^{60}$ questionando o monismo cultural próprio da criminologia liberal ${ }^{61}$ para formar a ideia de valores diferenciados convivendo em um mesmo espaço - pluralismo axiológico. É importante que não haja confusão entre o pluralismo e criminologia das subculturas, por que a teoria das subculturas é aliada à ideia de uma cultura predominante ${ }^{62}$ em convivência conflituosa com culturas inferiores, enquanto o pluralismo substitui o modelo monolítico de análise social da segunda por uma perspectiva dinâmica e contínua de corte democrático, conforme Shecaira. ${ }^{63}$

A ideia de um etiquetamento parte da premissa de que o determinismo da etiologia é resultado de um processo de criminalização que parte da ontologia para explicar a existência dos desvios sociais e, assim, leva o estudo da criminologia ao homem criminoso como uma realidade objetiva, ${ }^{64}$ ainda que sociologicamente considerado, ${ }^{65}$ associando o "ser" estatal real ao "dever ser" estatal ideal, segundo Zaffaroni e Nilo Batista. Associação que parte da "negação dos defeitos dos estados de direito reais pela construção de uma teoria do direito penal como se tais defeitos não existissem e o estado real fosse análogo ao ideal". ${ }^{66}$

Nesse sentido, Howard Becker embarca na crítica sociológica à ontologia do fenômeno criminal - como o dado pré-constituído à reação social ${ }^{67}$ - demonstrando que o objeto de estudo "criminalidade" é uma realidade social construída dentro de uma experiência cognoscitiva e prática e não anterior a ela, ontologicamente, ${ }^{68}$ para se afastar da velha criminologia e superar as "leituras fragmentadas que isolam as pessoas do complexo contexto em que vivem", ${ }^{69}$ como afirma Salo de Carvalho. Assim, a relação entre desviante e sociedade muda sua perspectiva metodológica para dizer que o crime não constitui uma patologia objetivamente própria do

\footnotetext{
${ }^{60}$ ZAFFARONI, Eugenio Raúl. A questão criminal. trad. Sérgio Lamarão. 1. ed. Rio de Janeiro: Revan, 2013. p. 134.

${ }^{61}$ BARATTA, A. Criminologia crítica e crítica do Direito Penal: introdução à sociologia do Direito Penal. Trad. Juarez Cirino dos Santos. 3. ed. Rio de Janeiro: Revan, 2002. p. 87.

62 ZAFFARONI, Eugenio Raúl. A questão criminal. trad. Sérgio Lamarão. 1. ed. Rio de Janeiro: Revan, 2013. p. 123.

${ }^{63}$ SHECAIRA, Sérgio Salomão. Criminologia. 6. ed. São Paulo: Revista dos Tribunais, 2014. p. 241.

${ }^{64}$ BATISTA, Vera Malaguti. Introdução crítica à criminologia brasileira. 2.ed. Rio de Janeiro: Revan, 2011 . p. 74.

${ }^{65}$ BARATTA, A. Criminologia crítica e crítica do Direito Penal: introdução à sociologia do Direito Penal. Trad. Juarez Cirino dos Santos. 3. ed. Rio de Janeiro: Revan, 2002. p. 89.

${ }^{66}$ ZAFFARONI, Eugenio Raul; BATISTA, Nilo. Direito Penal Brasileiro: teoria geral do Direito Penal. Vol. I. 4. ed. Rio de Janeiro: Revan, 2011. p. 615.

${ }^{67}$ BARATTA, A. Criminologia crítica e crítica do Direito Penal: introdução à sociologia do Direito Penal. Trad. Juarez Cirino dos Santos. 3. ed. Rio de Janeiro: Revan, 2002. p. 40

${ }^{68}$ Ibidem. p. 86.

${ }^{69}$ CARVALHO, Salo de. Antimanual de criminologia. 6. ed. rev. e ampl. São Paulo: Saraiva, 2015. p. 442.
} 
desviante, e também não constitui um defeito de socialização: o desvio só é assim considerado devido ao rótulo social que estabelece uma carga negativa a determinadas condutas e reage diante de suas práticas, ${ }^{70}$ sendo, portanto, artificial.

A mudança na perspectiva metodológica do conceito de criminoso associado à quebra de valores, como elementos sociais integralmente compartilhados, faz fragmentar a ideologia penal de defesa social em nome da perspectiva interacionista do novo enfoque, segundo Vera Malaguti Batista, ${ }^{71}$ direcionada por John Dewey - interação social - e George Mead psicologia coletiva - já que, agora, "homens de bem" foram tocados pelo direito penal. Shecaira exemplifica a situação de conflito que surge em 1968 quando, por ocasião de uma violenta repressão policial contra uma manifestação, Chicago vê, como resultado, uma enormidade de mortos e feridos. $^{72}$

A artificialidade, entendida como uma realidade social atribuída, ${ }^{73}$ é utilizada para demonstrar os processos discriminatórios, seletivos e rotuladores praticados pelas políticas criminais tradicionais, ${ }^{74}$ por que, segundo a corrente do interacionismo simbólico de que se vale o etiquetamento para demonstrar suas constatações, a atribuição de um papel, positivo ou negativo, gera a expectativa de que ele seja correspondido pelo atribuído, sendo que "nos aborrecemos quando ele não as responde da forma adequada ao papel". 75

Partindo da ideia de que qualquer núcleo social possui uma estrutura de poder com segmentos mais próximos e segmentos mais marginalizados de seu centro de exercício, ${ }^{76}$ ao passo em que não há aquele no qual exista um todo pacífico e sem fissuras interiores - ideia substituída pela noção de pluralidade de valores ${ }^{77}$ - e que tal núcleo tem sustentação na prática de um controle social, quando pautado pelas políticas criminais tradicionais, depois de constatada a situação de artificialidade da realidade social atribuída, é ilegítimo, pois se

\footnotetext{
${ }^{70}$ ANITUA, Gabriel Ignacio. Histórias dos pensamentos criminológicos. trad. Sérgio Lamarão. 1. reimp. Rio de Janeiro: Revan, 2015. p. 588.

${ }^{71}$ BATISTA, Vera Malaguti. Introdução crítica à criminologia brasileira. 2.ed. Rio de Janeiro: Revan, 2011. p. 73.

${ }^{72}$ SHECAIRA, Sérgio Salomão. Criminologia. 6. ed. São Paulo: Revista dos Tribunais, 2014. p. 247.

${ }^{73}$ BATISTA, Vera Malaguti. Introdução crítica à criminologia brasileira. 2.ed. Rio de Janeiro: Revan, 2011. p. 77.

${ }^{74}$ Ibidem. p. 77.

${ }^{75}$ ZAFFARONI, Eugenio Raúl. A questão criminal. trad. Sérgio Lamarão. 1. ed. Rio de Janeiro: Revan, 2013. p. 138.

${ }^{76}$ LOPES, Mauricio Antonio Ribeiro. Princípios políticos do direito penal. 2. ed. São Paulo: Revista dos Tribunais, 1999. p. 39.

${ }^{77}$ SHECAIRA, Sérgio Salomão. Criminologia. 6. ed. São Paulo: Revista dos Tribunais, 2014. p. 241.
} 
manifesta de modo seletivo e rotulador, transformando pessoas em inimigos quando lhes são negadas a condição de pessoa, conforme Zaffaroni, ao falar sobre a formação do inimigo no direito penal. ${ }^{78}$

O conceito de "outsider", ${ }^{79}$ como é desenvolvido na teoria de Becker, retrata a exclusão daquele que está fora do processo civilizatório e os problemas enfrentados, pela sociedade, para que faça dele um componente útil nesse processo. A rigor, é o inimigo, conforme Becker, sendo aquele que não se encaixa na sociedade de valor único a ser protegida e, por essa razão, é mais prático que seja excluído por meio da criminalização e cárcere quando o etiquetamento é aplicado com êxito.$^{80}$ Em um contexto de globalização $0^{81}$ das políticas de tolerância zero, como ficou demonstrado, eram muitos os criminalizados e as consequências do pós-encarceramento são entendidas como um processo complexo, objeto de estudo da teoria do etiquetamento quando ela traz as contribuições da psicologia, desenvolvida por Edwin Lemert, ${ }^{82}$ para demonstrar os efeitos da criminalização sobre o encarcerado - e acaba por conduzir a teoria ao desenvolvimento de uma etiologia muito sutil. ${ }^{83}$

Segundo Zaffaroni, Becker percebeu que há uma empresa moral que faz regras e que não é estudada, ao passo em que existem aqueles que passam pela aplicação da etiqueta de imoralidade e são os exclusivamente estudados. Essa seleção do objeto de estudo provoca uma rotulação que "coloca a pessoa em outro status, que a impede de continuar sua vida normal (...) foi condicionada a ele uma carreira, conforme a etiqueta que se lhe foi colocada", ${ }^{84}$ conforme explicou Lemert.

A carreira criminosa imposta, chamada de processo de rotulação, ao atribuir certas características ao indivíduo, conforme Anitua, expulsa o rotulado da sociedade honrada para que seja recebido pela “delinquencial, já que só entre outros delinquentes pode encontrar afeto,

\footnotetext{
78 ZAFFARONI, Eugenio Raúl. O inimigo no direito penal. 3. ed. Rio de Janeiro: Revan, 2007. p. 25.

${ }^{79}$ BECKER, Howard. Estudos de Sociologia do Desvio - Outsiders. 1. ed. Rio de Janeiro: Zahar, 2008. p. 1.

${ }^{80}$ ANITUA, Gabriel Ignacio. Histórias dos pensamentos criminológicos. trad. Sérgio Lamarão. 1. reimp. Rio de Janeiro: Revan, 2015. p. 592.

${ }^{81}$ WACQUANT, Loïc. As prisões da miséria. 2. ed. Rio de Janeiro: Zahar, 2011. p. 38.

${ }^{82}$ ANITUA, Gabriel Ignacio. Histórias dos pensamentos criminológicos. trad. Sérgio Lamarão. 1. reimp. Rio de Janeiro: Revan, 2015. p. 590.

${ }^{83}$ BARATTA, A. Criminologia crítica e crítica do Direito Penal: introdução à sociologia do Direito Penal. Trad. Juarez Cirino dos Santos. 3. ed. Rio de Janeiro: Revan, 2002. p. 91.

${ }^{84}$ ZAFFARONI, Eugenio Raúl. A questão criminal. trad. Sérgio Lamarão. 1. ed. Rio de Janeiro: Revan, 2013. p. 139.
} 
reconhecimento, aceitação e até prestígio", ${ }^{85}$ sendo que, em seguida, esse rotulado se adapta ao desvio como forma natural de vida. É importante relembrar que Robert Merton já havia demonstrado as consequências da pressão de sucesso econômico em disparidade com as possibilidades de se alcançar esse sucesso - distanciamento entre fins culturais e meios institucionais. $^{86}$

Existe, portanto, um processo de recepção e incorporação do estigma ${ }^{87}$ à personalidade do próprio estigmatizado - criminalização primária - ao passo em que existe também um processo de identificação entre o rotulado e grupos de rotulados - criminalização secundária. ${ }^{88}$ A rejeição social dificulta qualquer forma de reintegração do outsider à sociedade "honrada", forçando-o: a incorporar definitivamente o papel social que lhe foi imposto, conforme já havia prescrito Goffman no paralelo entre o teatro e a sociedade do interacionismo simbólico; ${ }^{89} \mathrm{se}$ identificar a outro grupo marginalizado; se juntar ao grupo seleto de estigmatizados e fazer parte da reprodução ideológica ${ }^{90}$ de seus valores internos: como dito, em um sistema que não consegue reproduzir nada além dele mesmo. Parte daí a crítica ao sutil desenvolvimento de uma etiologia determinista.

A implicação da reprodução ideológica é muito forte nesse sentido de consideração do mergulho no papel criminoso, chamado de role engulfment. ${ }^{91}$ A ideologia, ${ }^{92}$ para Althusser, filósofo do pensamento marxista, é um dado estruturalmente estabelecido na sociedade, sem existência própria ou construção a partir do indivíduo ou de seu grupo, se trata, pois, de um mecanismo estrutural material articulado por práticas materiais que correspondem a padrões ideológicos já estruturados socialmente pela escolha dos meios de produção ${ }^{93}$ - criminosos, para os outsiders.

\footnotetext{
${ }^{85}$ ANITUA, Gabriel Ignacio. Histórias dos pensamentos criminológicos. trad. Sérgio Lamarão. 1. reimp. Rio de Janeiro: Revan, 2015. p. 589.

${ }^{86}$ BARATTA, A. Criminologia crítica e crítica do Direito Penal: introdução à sociologia do Direito Penal. Trad. Juarez Cirino dos Santos. 6. ed. Rio de Janeiro: Revan, 2014. p. 64.

${ }^{87}$ Ibidem. p. 89.

${ }^{88}$ SHECAIRA, Sérgio Salomão. Criminologia. 6. ed. São Paulo: Revista dos Tribunais, 2014. p. 261.

${ }^{89}$ ZAFFARONI, Eugenio Raúl. A questão criminal. trad. Sérgio Lamarão. 1. ed. Rio de Janeiro: Revan, 2013. p. 137.

${ }^{90}$ ALTHUSSER, Louis. Aparelhos Ideológicos de Estado. 10. ed. Rio de Janeiro: Graal, 2007. p. 52.

${ }^{91}$ SHECAIRA, Sérgio Salomão. Criminologia. 6. ed. São Paulo: Revista dos Tribunais, 2014. p. 261.

${ }^{92}$ ALTHUSSER, Louis. Aparelhos Ideológicos de Estado. 10. ed. Rio de Janeiro: Graal, 2007. p. 52.

${ }^{93}$ MARX, Karl. Contribuição à Crítica da Economia Política. trad. Maria Helena Barreiro Alves. 5. ed. São Paulo: WMF Martins Fontes, 2016. p. 301.
} 
É, portanto, dizer que a ideologia correspondente ao conjunto de valores sociais é e faz o indivíduo, entendido como um ser espiritual nela imerso desde a sua concepção, logo, a ideologia não faz parte dele como um ente autônomo, ou como expressão de sua consciência individual, ${ }^{94}$ nem mesmo se impõe a ele contra sua vontade, mas o sujeita para se reproduzir sem que ele possa sequer perceber e o identifica enquanto ser socialmente considerado. ${ }^{95} \mathrm{~A}$ identificação socialmente considerada do ser criminoso, que incorporou esse papel, se materializa quando a "sociedade honrada" confirma o rótulo que havia imposto ainda na criminalização primária. $^{96}$

Baratta coloca em relevo uma polêmica iniciada pela criminologia alemã, quando da recepção da teoria do etiquetamento, que não negou a função da teoria, mas objetivou a superação da sutil etiologia que ela acabou por produzir. ${ }^{97}$ Explica Baratta que os alemães identificaram incongruências internas na teoria do etiquetamento, destacando Wolfgang, que identificou resíduos do paradigma etiológico na ideia de que o desviante rotulado como tal acaba por incorporar o status de desviante. A afirmação de que "se tratamos como criminosa uma pessoa, é provável que ela se torne criminosa" não é diversa do paradigma etiológico. ${ }^{98}$

A título de exemplo, “os positivistas chamaram de 'criminalidade' ao conjunto de presos, que era o único a que tinham acesso, porque os muitos mais que cometiam delitos e ficavam impunes lhes eram desconhecidos". ${ }^{99}$ Esse recorte de Zaffaroni aplica a questão do etiquetamento à crítica do positivismo bioantropológico, ao mesmo tempo em que dá possibilidade de se demonstrar como a etiologia não se desvencilhou por completo com o novo enfoque. Outro exemplo é a utilização da gradiente tendency ${ }^{100}$ pelos sociólogos de Chicago, a partir de Ernest Burgess, para fazer a divisão geográfica ${ }^{101}$ da cidade em zonas concêntricas e

\footnotetext{
94 BILLIER, Jean-Cassien; MARYIOLI, Aglaé. História da Filosofia do Direito. Trad. Maurício de Andrade. 1. ed. Barueri, SP: Manole, 2005. p. 341.

${ }^{95}$ MASCARO, Alysson Leandro. Filosofia do Direito. 3. ed. São Paulo: Atlas, 2013. p. 558.

96 ANITUA, Gabriel Ignacio. Histórias dos pensamentos criminológicos. trad. Sérgio Lamarão. 1. reimp. Rio de Janeiro: Revan, 2015. p. 593.

${ }^{97}$ BARATTA, A. Criminologia crítica e crítica do Direito Penal: introdução à sociologia do Direito Penal. Trad. Juarez Cirino dos Santos. 3. ed. Rio de Janeiro: Revan, 2002. p. 91.

98 Ibidem. p. 93.

${ }^{99}$ ZAFFARONI, Eugenio Raúl. A questão criminal. trad. Sérgio Lamarão. 1. ed. Rio de Janeiro: Revan, 2013. p. 81.

${ }^{100}$ SHECAIRA, Sérgio Salomão. Criminologia. 6. ed. São Paulo: Revista dos Tribunais, 2014. p. 150.

101 ZAFFARONI, Eugenio Raúl. A questão criminal. trad. Sérgio Lamarão. 1. ed. Rio de Janeiro: Revan, 2013. p. 121.
} 
identificar quem frequenta, quem reside em cada uma das áreas e quais são as áreas mais e menos afetadas pela criminalidade.

Ou seja, segundo a etiologia, a criminalidade está ali, em algum local, seja no sujeito bioantropologicamente considerado, seja no meio social que em que vive. Com o enfoque do etiquetamento, a criminalidade também tem um local determinado e está naqueles que sofrem a reação social e têm a possibilidade de aderir ao papel de criminoso. É realmente sutil, mas a etiologia ainda está presente na criminologia liberal do etiquetamento, conforme a interferência entre ambos constatada por Wolfgang. ${ }^{102}$

\subsection{A teoria do etiquetamento levada ao paralelo literário de Machado de Assis: o alienista como a empresa moral da reta razão, sua convencionalidade interpretativa e a síntese da seletividade.}

Não obstante a crítica que a teoria do etiquetamento sofreu quando de sua recepção alemã, a fenomenologia existencialista heideggeriana, ${ }^{103}$ utilizada na fundação da perspectiva criminológica na qual a teoria embarcou segundo o enfoque do interacionismo simbólico, ${ }^{104}$ trouxe a ideia de que o conhecimento sobre a realidade social deve partir do sentido dado às coisas por sua construção concreta e, assim, produziu efeitos também na psiquiatria, que, até 1960, trabalhava no campo criminológico com a ideologia do tratamento do desviante. ${ }^{105}$

O reflexo da fenomenologia no específico campo da criminologia do tratamento do desviante gerou um movimento de antipsquiatria, exatamente no mesmo sentido refletido na criminologia que buscou a etiologia do crime, aqui trabalhada a partir daquela produzida por Durkheim. ${ }^{106}$ Tendo em vista que a ideia de existência de um desvio ontologicamente considerado começou a ser severamente questionada, "seria radicalmente questionado o próprio

\footnotetext{
102 BARATTA, A. Criminologia crítica e crítica do Direito Penal: introdução à sociologia do Direito Penal. Trad. Juarez Cirino dos Santos. 3. ed. Rio de Janeiro: Revan, 2002. p. 94.

${ }^{103}$ BILLIER, Jean-Cassien; MARYIOLI, Aglaé. História da Filosofia do Direito. Trad. Maurício de Andrade. 1. ed. Barueri, SP: Manole, 2005. p. 362.

${ }^{104}$ BARATTA, A. Criminologia crítica e crítica do Direito Penal: introdução à sociologia do Direito Penal. Trad. Juarez Cirino dos Santos. 3. ed. Rio de Janeiro: Revan, 2002. p. 87.

105 ANITUA, Gabriel Ignacio. Histórias dos pensamentos criminológicos. trad. Sérgio Lamarão. 1. reimp. Rio de Janeiro: Revan, 2015. p. 586.

${ }^{106}$ BATISTA, Vera Malaguti. Introdução crítica à criminologia brasileira. 2.ed. Rio de Janeiro: Revan, 2011. p.65.
} 
conceito de loucura ou doença mental, entendido como uma condição patológica ou anormal". ${ }^{107}$ Anitua ainda acrescenta que também seria questionada a pretensão científica da psiquiatria e da psicologia que, por conta de seus dogmas científicos, parecia mais uma religião. ${ }^{108}$

$\mathrm{Na}$ cidade de Itaguaí, Dr. Bacamartes se manteve aficionado em sua ciência, pela qual acreditou ser a solução para todos os males dos "pobres doidos" de toda espécie, como dito. Inaugurou sua Casa Verde e fez dela o local de aglomeração e estudo da loucura, fazendo dos dogmas da pretensão científica psiquiátrica seu estilo de vida. Conta Machado de Assis que, a certa altura de seus estudos, logo depois que procedeu a vasta classificação dos seus enfermos, o alienista fez com que seu trabalho levasse o melhor e maior do seu tempo. ${ }^{109}$

Ainda que acreditasse em seu trabalho com toda a força de sua convicção científica, assim como nos vários eventos e fatores ${ }^{110}$ que antecederam a reformulação da criminologia liberal para fundação da teoria do etiquetamento, ${ }^{111} \mathrm{o}$ alienista não foi capaz de manter o rígido controle e aprovação que mantinha sobre a sociedade de Itaguaí, sendo severamente questionado a tons de "tirano, déspota e golias", ${ }^{112}$ logo após fazer sua ciência tocar os estimados cidadãos Costa, sua prima, pobre senhora, Mateus, o albardeiro, Martin Brito e mais alguns outros. Lembrando o que Shecaira chama de "fermento de ruptura com a velha criminologia", não foi diferente com política criminal de tolerância zero quando, de uma hora para outra, suas aplicações "transformaram pessoas comuns em criminosos". 113

Assim como o discurso da defesa social pelo mínimo ético ${ }^{114}$ se desgastou na sociedade norte-americana da década de 60, o discurso da reta razão alcançada pelo rigor científico da psiquiatria de Bacamartes perdeu a aprovação popular, causando o que Machado de Assis

\footnotetext{
107 ANITUA, Gabriel Ignacio. Histórias dos pensamentos criminológicos. trad. Sérgio Lamarão. 1. reimp. Rio de Janeiro: Revan, 2015. p. 579.

108 ANITUA, Gabriel Ignacio. Histórias dos pensamentos criminológicos. trad. Sérgio Lamarão. 1. reimp. Rio de Janeiro: Revan, 2015. p. 579.

${ }^{109}$ ASSIS, Machado de. Obra Completa. Rio de Janeiro: Nova Aguilar, 1994. p. 4.

110 GARLAND, David. A cultura do Controle: crime e ordem social na sociedade contemporânea. Rio de Janeiro: Revan, 2014. p. 181.

111 ZAFFARONI, Eugenio Raúl. A questão criminal. trad. Sérgio Lamarão. 1. ed. Rio de Janeiro: Revan, 2013. p. 134.

112 ASSIS, Machado de. Obra Completa. Rio de Janeiro: Nova Aguilar, 1994. p. 12.

${ }^{113}$ SHECAIRA, Sérgio Salomão. Criminologia. 6. ed. São Paulo: Revista dos Tribunais, 2014. p. 255.

114 BARATTA, A. Criminologia crítica e crítica do Direito Penal: introdução à sociologia do Direito Penal. Trad. Juarez Cirino dos Santos. 6. ed. Rio de Janeiro: Revan, 2014. p. 76.
} 
chamou de rebelião, a revolta de cerca de trinta e cinco pessoas ligadas ao barbeiro de Itaguaí. ${ }^{115}$ Bradavam os agitadores irritados que "muitas pessoas estimáveis, e algumas distintas, outras humildes mas dignas de apreço, jaziam nos cubículos da Casa Verde."116

A resposta da Câmara de Itaguai à representação dos trinta e cinco revoltosos não fez diferente ao que Karl Marx já havia prescrito em relação ao direito, ${ }^{117}$ fundamentando sua recusa em aceitar as reinvindicações pelo caráter de instituição pública da Casa Verde e pela ideia de que a ciência não poderia ser emendada por votação administrativa, "menos ainda por movimentos de rua". ${ }^{118}$ Karl Marx demonstrou o caráter de mecanismo de manutenção do status quo que o direito assume ao se levantar a partir de uma específica estrutura econômica social ${ }^{119}$ para atuar como um mecanismo superestrutural de manutenção do poder que domina sobre os que são dominados. ${ }^{120}$

O subsequente problema enfrentado pela Câmara de Itaguaí reside no que também apresentou Karl Marx ao falar das contenções ideológicas da superestrutura: ${ }^{121}$ explicou como a consciência de classe, as contradições e conflitos internos resultam no total ou parcial rompimento com a base de sustentação do poder exercido por meio do direito - a força da revolução. ${ }^{122}$ No sentido marxista, Althusser explica que tal rompimento acontece quando os mecanismos de controle falham, sobretudo em reafirmar a infraestrutura social, ${ }^{123}$ ao passo em que a superestrutura social reformula suas justificações e se põe em atuação fundamentada em novas explicações - agora ajustada às necessidades dos insurgentes infraestruturais.

A diferença entre a realidade estadunidense da década de 60 e o paralelo literário está no fato de que a criminologia liberal rapidamente tratou de reformular seus fundamentos para

\footnotetext{
115 ASSIS, Machado de. Obra Completa. Rio de Janeiro: Nova Aguilar, 1994. p. 12.

116 Ibidem. p. 12.

$117 \mathrm{O}$ direito se constitui pela necessidade histórica de as relações produtivas capitalistas estabelecerem determinadas instâncias que possibilitem a própria reprodução do sistema, como afirma Alysson Mascaro. MASCARO, Alysson Leandro. Filosofia do Direito. 3. ed. São Paulo: Atlas, 2013. p. 294

118 ASSIS, Machado de. Obra Completa. Rio de Janeiro: Nova Aguilar, 1994. p. 12.

${ }^{119}$ MARX, Karl. Contribuição à Crítica da Economia Política. trad. Maria Helena Barreiro Alves. 5. ed. São Paulo WMF Martins Fontes, 2016. p. 301.

${ }^{120}$ BITTAR, Eduardo C.B.; ALMEIDA, Guilherme Assis de. Curso de Filosofia do Direito. 10. ed. São Paulo: Atlas, 2012. p. 383.

${ }^{121}$ FILHO, Arnaldo Lemos, et. al. Sociologia Geral e do Direito. 6. ed. Campinas: Alínea, 2014. p. 112.

122 BITTAR, Eduardo C.B.; ALMEIDA, Guilherme Assis de. Curso de Filosofia do Direito. 10. ed. São Paulo: Atlas, 2012. p. 383.

${ }^{123}$ ALTHUSSER, Louis. Aparelhos Ideológicos de Estado. 10. ed. Rio de Janeiro: Graal, 2007. p. 65.
} 
a existência dos processos de criminalização, ${ }^{124}$ ao passo em que trouxe fundamentos deslegitimadores das penas aplicadas ao criminalizados para que, mesmo dando resultados limitados, ${ }^{125}$ pudesse manter contida a base revoltosa - o que é objeto de crítica da criminologia radical $^{126}$ - enquanto em Itaguaí, o que se buscou, foi a organização de uma rebelião que pudesse reestruturar toda a base política que dava legitimidade ao alienista para praticar o que a comunidade chamou de "cárcere privado", ${ }^{127}$ sem que pudesse haver qualquer mecanismo capaz de reformular as justificações da ciência do alienista e de sua "Bastilha da razão humana"128

E assim aconteceu no pequeno vilarejo, o que era entendido pelo presidente da Câmara como um "turbilhão de átomos dispersos", mesmo após a sensatez de Sebastião Freitas, vereador que se sensibilizou à rebelião, alertar que possivelmente o alienado poderia ser o próprio alienista, passou de trinta para trezentas pessoas em sentimento unânime. O movimento de revolta teve seu desfecho logo após a sangrenta tomada do poder da Câmara pelo barbeiro apelidado de Canjica, que, logo após libertar aqueles que bradava ser estimados cidadãos pessoas estimáveis, e algumas distintas, outras humildes mas dignas de apreço $^{129}$ inesperadamente demonstrou ser simpático à ciência da reta razão e manteve o alienista no comando da Casa Verde, sob alegação de que, fora aqueles que havia libertado e alguns tantos outros, o governo não cogitaria resolver as questões que só a ciência poderia resolver.

Como dito, a sociologia criminológica deu vida à inédita premissa de que não há uma realidade ontológica do delito, para afirmar que "o mesmo delito não seria definido por suas causas e consequências, como dizia o paradigma etiológico, mas sim por sua convencionalidade interpretativa". ${ }^{130}$ A convencionalidade interpretativa é a síntese do referido

\footnotetext{
${ }^{124}$ ZAFFARONI, Eugenio Raúl. A questão criminal. trad. Sérgio Lamarão. 1. ed. Rio de Janeiro: Revan, 2013. p. 134.

${ }^{125}$ BATISTA, Vera Malaguti. Introdução crítica à criminologia brasileira. 2.ed. Rio de Janeiro: Revan, 2011. p. 74.

126 YOUNG, Jock. A sociedade excludente: exclusão social, criminalidade e diferença na modernidade recente. Trad. Renato Aguiar. 3. rei. Rio de Janeiro: Revan, 2015. p. 150.

127 ASSIS, Machado de. Obra Completa. Rio de Janeiro: Nova Aguilar, 1994. p. 10.

${ }^{128}$ Ibidem. p. 13.

${ }^{129}$ Ibidem. p. 12.

${ }^{130}$ ANITUA, Gabriel Ignacio. Histórias dos pensamentos criminológicos. trad. Sérgio Lamarão. 1. reimp. Rio de Janeiro: Revan, 2015. p. 586.
} 
papel atribuído ao direito por Karl Marx, ${ }^{131}$ onde o poder dominante utiliza este instrumento de contenção superestrutural para selecionar o que é considerado desvio ao processo civilizatório e garantir a reprodução desse poder - assim como o barbeiro Canjica rapidamente tratou de selecionar e reproduzir ao assumir o poder. É o que Zaffaroni demonstra ao tratar da indisponibilidade do conceito de estereótipo ${ }^{132}$ para explicar a seletividade criminalizadora policial ou judicial que veio após a formulação do panorama do interacionismo simbólico.

Ou seja, para romper com a "questão causal e da percepção do crime como qualidade intrínseca do autor da conduta", ${ }^{133}$ a ideia de luta do bem contra o mal é quebrada com a chegada do panorama do etiquetamento, por que este demonstrou que a correspondência negativa entre determinadas práticas de grupos e valores sociais únicos e sua criminalização partem de interpretações, definições ${ }^{134}$ e reações ${ }^{135}$ que variam de acordo com o interesse do poder. $\mathrm{O}$ ponto de partida das interpretações, definições e reações é a empresa moral não estudada, ${ }^{136}$ onde são feitas as regras, conforme definiu Becker, enquanto são exclusivamente estudadas as pessoas "às quais lhes é aplicada a etiqueta que as deixa fora". ${ }^{137}$ Essa nova perspectiva é uma inversão da ideologia da defesa social até então preponderante, por que propõe o estudo mais concentrado em quem faz as regras e menos em quem as transgride.

Dr. Bacamartes é a empresa moral que deve ser estudada, lembrando que a obra de Machado de Assis não dá qualquer outra pista sobre os critérios utilizados pelo alienista para internar seus loucos, senão sua própria reta razão. A questão fica ainda mais nítida em Itaguaí quando, após a queda de Canjica do poder e estabilização da situação governamental quando do reestabelecimento da ordem pela força mandada pelo vice-rei, o alienista promove uma coleta desenfreada de loucos, inclusive de Canjica, e subitamente, com fundamento científico (sic) muda o rumo de seus experimentos para libertar todos os alojados em seu manicômio,

\footnotetext{
131 O direito se constitui pela necessidade histórica de as relações produtivas capitalistas estabelecerem determinadas instâncias que possibilitem a própria reprodução do sistema, como afirma Alysson Mascaro. MASCARO, Alysson Leandro. Filosofia do Direito. 3. ed. São Paulo: Atlas, 2013. p. 294

132 ZAFFARONI, Eugenio Raúl. A questão criminal. trad. Sérgio Lamarão. 1. ed. Rio de Janeiro: Revan, 2013. p. 141.

${ }^{133}$ CARVALHO, Salo de. Antimanual de criminologia. 6. ed. rev. e ampl. São Paulo: Saraiva, 2015. p. 91.

134 BARATTA, A. Criminologia crítica e crítica do Direito Penal: introdução à sociologia do Direito Penal. Trad. Juarez Cirino dos Santos. 3. ed. Rio de Janeiro: Revan, 2002. p. 86.

135 ANITUA, Gabriel Ignacio. Histórias dos pensamentos criminológicos. trad. Sérgio Lamarão. 1. reimp. Rio de Janeiro: Revan, 2015. p. 588.

136 ZAFFARONI, Eugenio Raúl. A questão criminal. trad. Sérgio Lamarão. 1. ed. Rio de Janeiro: Revan, 2013. p. 139.

${ }^{137}$ Ibidem. p. 139.
} 
para espanto da comunidade, e encarcerar as pessoas demasiadas sãs; diziam os cidadãos da vila "é impossível; alguns sim, mas todos...". 138

Após praticar sua doutrina de internação em rigor científico paralelo à política de aprisionamento $^{139}$ da tolerância zero, eram tantos os loucos que o alienista concluiu, em seu ofício enviado à Câmara, que "devia admitir como normal e exemplar o desequilíbrio das faculdades e como hipóteses patológicas todos os casos em que aquele equilíbrio fosse ininterrupto", ${ }^{140}$ casos que seriam agasalhados pela Casa Verde.

Enfim, demonstrou Machado de Assis que todos os eventos ocorridos com a cidade de Itaguaí, relativamente à Casa Verde e Dr. Bacamartes, nunca se trataram de uma busca real pela cura do mal protagonizando o bem, mas que todos esses eventos passaram pelo rígido controle interpretativo exercido de modo déspota pelo homem da ciência, apoiado politicamente e amparado por sua reta razão. Conclui o autor, segundo os relatos dos cronistas, que nunca houve outro louco, além do próprio cientista na cidade de Itaguaí, ${ }^{141}$ que, após perceber em si mesmo todas as qualidades morais positivas que entendia próprias de um mentecapto em perfeito equilíbrio mental e moral, resolveu por se recolher a sua própria Casa Verde.

Não houve jamais um mal que não fosse aquele seletivamente rotulado como tal pelo alienista detentor da empresa moral. Como explicam Zaffaroni e Nilo Batista, ${ }^{142}$ o poder punitivo criminaliza: selecionando pessoas que, em regra, se enquadram nos estereótipos e, por essa razão, se tornam vulneráveis por desempenhar o papel induzido (os pobres loucos de Itaguaí); selecionando as pessoas que, sem se enquadrarem no estereótipo, acabam por se tornar vulneráveis (o estimado Costa e sua prima); por fim, selecionando alguém que muito excepcionalmente se torna vulnerável quando leva a pior parte em uma luta de poder hegemônico (o babeiro Canjica). Nesse sentido, a teoria do etiquetamento demonstrou que jamais houve uma luta entre o bem e o mal passando pelos processos de criminalização, ${ }^{143}$ tudo

\footnotetext{
138 ASSIS, Machado de. Obra Completa. Rio de Janeiro: Nova Aguilar, 1994. p. 20.

${ }^{139}$ DE GIORGI, Alessandro. A miséria governada através do sistema penal. 2. reimp. Rio de Janeiro: Revan, 2013. p. 85.

${ }^{140}$ ASSIS, Machado de. Obra Completa. Rio de Janeiro: Nova Aguilar, 1994. p. 20.

${ }^{141}$ ASSIS, Machado de. Obra Completa. Rio de Janeiro: Nova Aguilar, 1994. p. 26.

${ }^{142}$ ZAFFARONI, Eugenio Raul; BATISTA, Nilo. Direito Penal Brasileiro: teoria geral do Direito Penal. Vol. I. 4. ed. Rio de Janeiro: Revan, 2011. p. 49.

143 ANITUA, Gabriel Ignacio. Histórias dos pensamentos criminológicos. trad. Sérgio Lamarão. 1. reimp. Rio de Janeiro: Revan, 2015. p. 588.
} 
sempre se tratou de convencionalidade interpretativa de quem detém o poder de rotular, criminalizar e reagir às condutas contra o projeto civilizatório.

\section{CONCLUSÃO}

As dinâmicas de controle instrumentalizadas pela política criminal da tolerância zero entram em paralelo à obra de Machado de Assis quando o autor traz a crônica de Bacamartes, assíduo médico que praticou sua própria intolerância em nome da ciência e da cura universal.

Apesar de ser tratada, pela criminologia crítica de Alessandro Baratta, como um reformismo liberal, a teoria do etiquetamento representou um grande marco na criminologia, por que deu início ao questionamento dos processos de criminalização pautados pelo estereótipo social. Nesse sentindo também está o paralelo literário do alienista, por que, assim como a política de tolerância zero, Dr. Bacamartes partiu da ciência em reta razão para selecionar sua clientela, aos moldes da Escola Positivista em paradigma etiológico, procurando as causas da existência da anormalidade, segregando como forma de seleção e internando como forma de tratamento ambulatorial.

Respectivamente, o paradigma etiológico procurou as causas da existência da criminalidade, segregando como forma se seleção dos inadequados e encarcerando como forma de controle social pelo direito penal. Assim, conclui-se tópico a tópico que:

1 - Muito próximo da realidade estadunidense da segunda metade do século XX, o paralelo literário de Machado de Assis trouxe Dr. Bacamartes como o intolerante àquele que foge ao gênero, ao equilíbrio e à normalidade. Ao por em prática sua ciência, com autorização legislativa, povoou sua Casa Verde de loucos de toda espécie, sendo que, por não bastar seu projeto inicial, promoveu a expansão do local, entendendo existir uma explicação humana e puramente científica para o fenômeno da loucura desenfreada. $\mathrm{O}$ alienista analisou todos os aspectos sociais e psíquicos de seus loucos, assim como fez a metodologia da ecologia criminal aproximada do paradigma bioantropológico e, em certa altura, lhe foi sugerida a utilização da 
"matraca", assim como fez a propaganda dos seminários que espalharam as "teses do milagre" pelo globo.

2 - A Casa Verde já era um povoado de loucos quando o terror assolou a cidade de Itaguaí. Enquanto os indesejáveis eram internados e colocados em seu devido lugar segundo a ciência, o alienista contou com grande aprovação popular, o que mudou no momento em que "estimados cidadãos" foram recolhidos juntos aos indesejáveis. A ciência de Bacamartes expandiu suas fronteiras e, na perspectiva da comunidade de Itaguaí, perdeu o controle, por que tocou pessoas desejáveis de modo déspota e poderia tocar muitas outras, como aconteceu com a política de tolerância zero questionada pela teoria do etiquetamento.

3 - Assim como ao tempo da formulação da teoria do etiquetamento, os "fermentos de ruptura" com a ciência de Bacamartes só sobrevieram diante da internação de pessoas estimadas. Nos Estados Unidos da década de 60, a política de tolerância zero considerou como criminosos os ativistas dos movimentos pelos direitos das mulheres e dos negros, aqueles que, em forma de manifestações, se colocavam contra a Guerra do Vietnã, dentre muitos outros que, em síntese, eram as pessoas boas até então. Não obstante, a teoria trouxe uma revolução metodológica ao apresentar a ideia de que não há uma realidade ontológica do delito, já que, por uma convencionalidade interpretativa, não seria possível dizer que um mesmo delito não poderia ser definido por suas causas e consequências em paradigmas interpretativos diversos, refutando parte da etiologia para fugir de seu determinismo.

4 - A ideologia da defesa social é fragilizada com o novo enfoque criminológico, e disso vem o título de revolução científica, segundo Baratta, dando abertura ao início de um enfrentamento da legitimação dos processos de criminalização e da ideia de correspondência negativa entre o fenômeno da criminalidade e a quebra de valores sociais. Logo, com o novo enfoque, o crime finalmente deixa de ser entendido como representação do mal natural ou social para ser interpretado a partir da existência concreta e das construções sociais que edificam aparatos de contenção às violações que comprometem um projeto civilizatório.

5 - A teoria do etiquetamento não foi integralmente recepcionada pela criminologia alemã, que apontou uma sutil falha em sua pretensão de afastamento da etiologia, demonstrando Wolfgang que a ideia de que o outsider, rotulado como desviante, acaba por incorporar o status que lhe é atribuído socialmente, não é muito diferente da procura das causas da criminalidade 
que o paradigma etiológico buscou. Dessa forma, ainda que tenha iniciado o questionamento dos processos de criminalização, segundo o etiquetamento, a criminalidade ainda está em um lugar definido: naqueles que sofreram um processo de rotulação, assim como está no sujeito em si considerado para a criminologia moderna e está no seio social para a criminologia ecológica.

6 - Mesmo diante da crítica alemã, a fundação de uma nova perspectiva criminológica com o advento do enfoque do etiquetamento traz a possibilidade de se questionar os processos de criminalização, assim como traz a possibilidade de se questionar os dogmas científicos da psiquiatria do tratamento do desviante, conforme Anitua. Assim como o desvio ontologicamente considerado é refutado, o movimento antipsiquiatria coloca em crítica o próprio conceito de loucura patológica, aquela para a qual o alienista se propôs a encontrar a solução definitiva. Tendo por vista que inestimáveis cidadãos de Itaguaí jaziam na Casa Verde, como jaziam nobres estadunidenses, a reta razão do alienista deveria passar por uma reformulação, como passou a criminologia do mínimo ético estadunidense. Assim, a cidade logo tratou de promover uma rebelião para derrubar o despotismo de Bacamartes, perdurando somente até o exato momento em que foram libertos os estimados e mantidos os indesejados.

7 - O direito, entendido por Marx como instrumento de dominação, entendido pelo interacionismo simbólico como uma convencionalidade interpretativa e entendido pela teoria do etiquetamento como emanado de quem tem o poder de emanar - a empresa moral - nada mais fez que se readequar às exigências dos insurgentes e manter novamente a ordem, quando o barbeiro Canjica, líder da rebelião, manteve o alienista em produção de sua ciência. Nesse sentido, Zaffaroni prescreve ser indisponível o conceito de estereótipo para explicar a seletividade da criminalização, por que tal processo varia de acordo com o interesse do poder enquanto empresa moral que define e reage aos desvios conforme sua convencionalidade interpretativa voltada à dominação que garanta um determinado processo civilizatório.

8 - Bacamartes, materializado na figura de empresa moral, deixa bem claro seu despotismo ao final da obra, quando subitamente resolve por libertar todos os internos da Casa Verde, por que, a seu ver, era tanta a loucura que, na verdade, o anormal seria aquele que jamais tivesse apresentado qualquer sinal de desvio de sua reta razão. Sua busca nunca se tratou da cura do mal, senão aquela que ele mesmo criou pela reta razão, moldada conforme a filosofia da consciência, seletivamente rotulando e reagindo contra aqueles que imediatamente se 
enquadraram ao estereótipo, contra aqueles que se tornaram vulneráveis por qualquer outra forma e, por fim, contra aquele que muito excepcionalmente perdeu o poder hegemônico e se tornou vulnerável. No mais, com a nova teoria científica de que a loucura só poderia ser própria de quem jamais teve qualquer desequilíbrio, o alienista pôs-se enjaulado, dizendo os cronistas, conta Machado de Assis, que jamais ouve qualquer outro louco em Itaguaí que não fosse Dr. Bacamartes.

Assim, as políticas criminais pensadas e estruturadas por "doutores Bacamartes", a partir do maximalismo penal, se colocam em confronto direto e ostensivo com os modelos de garantia proporcionados pelo constitucionalismo europeu pós-segunda guerra mundial, que, na tentativa de evitar cometer novamente os erros próprios de sua história e demonstrar ao restante do mundo onde falhou, objetivando servir de exemplo, trouxe o homem ainda mais para o centro das reflexões, observando, no entanto, que somente discursar sua inegociável condição de sujeito de direito não é suficiente se o discurso não for acompanhado pela prática.

\section{REFERÊNCIAS}

ALTHUSSER, Louis. Aparelhos Ideológicos de Estado. 10. ed. Rio de Janeiro: Graal, 2007.

ANITUA, Gabriel Ignacio. Histórias dos pensamentos criminológicos. trad. Sérgio Lamarão. 1. reimp. Rio de Janeiro: Revan, 2015.

ASSIS, Machado de. Obra Completa. Rio de Janeiro: Nova Aguilar, 1994.

BARATTA, A. Criminologia crítica e crítica do Direito Penal: introdução à sociologia do Direito Penal. Trad. Juarez Cirino dos Santos. 6. ed. Rio de Janeiro: Revan, 2014.

BATISTA, Vera Malaguti. Introdução crítica à criminologia brasileira. 2.ed. Rio de Janeiro: Revan, 2011.

BECKER, Howard. Estudos de Sociologia do Desvio - Outsiders. 1. ed. Rio de Janeiro: Zahar, 2008.

BILLIER, Jean-Cassien; MARYIOLI, Aglaé. História da Filosofia do Direito. Trad. Maurício de Andrade. 1. ed. Barueri, SP: Manole, 2005.

BITTAR, Eduardo C.B.; ALMEIDA, Guilherme Assis de. Curso de Filosofia do Direito. 10. ed. São Paulo: Atlas, 2012. 
BITENCOURT, Cezar Roberto. Tratado de direito penal: parte geral. 17. ed. rev., ampl. e atual. São Paulo: Saraiva, 2012.

CARVALHO, Salo de. Antimanual de criminologia. 6. ed. rev. e ampl. São Paulo: Saraiva, 2015.

DE GIORGI, Alessandro. A miséria governada através do sistema penal. 2. reimp. Rio de Janeiro: Revan, 2013.

DIAS, Jorge Figueiredo; ANDRADE, Manual da Costa. Criminologia: o homem delinquente e a sociedade criminógena. Coimbra: Coimbra, 1997.

DURKHEIM, Émile. As regras do método sociológico. Trad. Paulo Neves. 3. ed. São Paulo: Martins Fontes, 2007.

DURKHEIM, Émile. O suicídio: estudo de sociologia. Trad. Monica Stahel. São Paulo: Martins Fontes, 2000.

FILHO, Arnaldo Lemos, et. al. Sociologia Geral e do Direito. 6. ed. Campinas: Alínea, 2014.

FOUCAULT, Michel. Vigiar e punir. 42. ed. Rio de Janeiro: Vozes, 1987.

GARLAND, David. A cultura do Controle: crime e ordem social na sociedade contemporânea. Rio de Janeiro: Revan, 2014.

LE GOFF, Jacques. Por amor às cidades: conversações com Jean Lebrun. trad. Reginaldo Carmello Corrêa de Moraes. São Paulo: UNESP, 1998.

LOPES, Mauricio Antonio Ribeiro. Princípios políticos do direito penal. 2. ed. São Paulo: Revista dos Tribunais, 1999.

MARX, Karl. Contribuição à Crítica da Economia Política. trad. Maria Helena Barreiro Alves. 5. ed. São Paulo: WMF Martins Fontes, 2016.

MASCARO, Alysson Leandro. Filosofia do Direito. 3. ed. São Paulo: Atlas, 2013.

PARK, Robert Ezra. A cidade: sugestões para a investigação do comportamento humano. Trad. Sérgio Magalhães Santeiro. Rio de Janeiro: Zahar, 1967.

REALE, Miguel. Fontes e modelos do direito: para um novo paradigma hermenêutico. São Paulo: Saraiva, 1994.

SHAW, Clifford R. The Jack-Roller: a delinquente boy's own story. Chicago: The University of Chicago Press, 1974.

SHECAIRA, Sérgio Salomão. Criminologia. 6. ed. São Paulo: Revista dos Tribunais, 2014. 
SILVA FILHO, Edson Vieira da. Há que se revisitar Kant em uma leitura do Direito Penal Contemporâneo?. In: FIGUEIREDO, E. H. L.; CAMPOS MONACO, G. F. de; MAGALHÃES, J. L. Q de. (Coord.). Constitucionalismo e Democracia. 1. ed. Rio de janeiro: Elsevier, 2012.

SUTHERLAND, Edwin H. Crime de colarinho branco: versão sem cortes. trad. Clécio Lemos. 1. ed. Rio de Janeiro: Revan, 2015.

WACQUANT, Loïc. As prisões da miséria. 2. ed. Rio de Janeiro: Zahar, 2011.

YOUNG, Jock. A sociedade excludente: exclusão social, criminalidade e diferença na modernidade recente. Trad. Renato Aguiar. 3. rei. Rio de Janeiro: Revan, 2015.

ZAFFARONI, Eugenio Raúl. A questão criminal. trad. Sérgio Lamarão. 1. ed. Rio de Janeiro: Revan, 2013.

Em busca das penas perdidas: a perda da legitimidade do sistema penal. trad. 32. Vania Romano Pedrosa, Amir Lopez da Conceição. 5. ed. Rio de Janeiro: Revan, 2001.

O inimigo no direito penal. 3. ed. Rio de Janeiro: Revan, 2007.

; BATISTA, Nilo. Direito Penal Brasileiro: Teoria Geral do Direito Penal. Vol. I. 4. ed. Rio de Janeiro: Revan, 2011.

Data de Submissão: 09/01/2019

Data de Aceite: 06/12/2019 